\title{
Giftedness as Property: Troubling Whiteness, Wealth, and Gifted Education in the United States
}

\author{
Katherine Cumings Mansfield \\ Virginia Commonwealth University \\ U.S.A.
}

ABSTRACT: The purposes of this article are to illumine the racist genealogy of gifted education policies and practices in the United States, to demonstrate how deficit discourses continue today, and to provide personal examples from the field of how educators can begin to question the status quo, resist taken-for-granted assumptions, and alternatively make substantive changes at the local level. I also aim to demonstrate how giftedness is an example of whiteness as property, or unearned white privilege, that, unintentionally or not, maintains a social caste system in schools.

KEY WORDS: gifted education, education policy, racism, Whiteness, educational leadership

\author{
Methodology \\ Findings \\ Discussion \\ Implications and Illustrations \\ Conclusion \\ Notes \\ References
}

Relatively recent research is operationalizing the concept of white privilege and encouraging educational leaders to participate in courageous conversations about race in order to create more equitable schooling practices (Brooks \& Arnold, 2013; McIntosh, 1990; Singleton \& Linton, 2005). While this work is useful and even indispensable, until relatively recently research in this area has lacked the specificity that can potentially move the conversation forward. To fill that gap, this article examines important details around a neglected topic: the troubling discourse around gifted education in the United States.

Examining the field of gifted education with greater specificity is important for a number of reasons. First, there are problems defining, identifying, and serving the gifted and talented (GT) triggering stark underrepresentation of minoritzed ${ }^{1}$ children and youth in gifted programs and advanced placement coursework (Oakes, 2005; Valdés, 2003; Valencia, 2010; Valencia \& Suzuki, 2001). Second, the origin of these problems is seriously disputed in the literature. For example, Herrnstein and Murray (1994), Johnsen (2004), and Slocumb \& Payne (2000) blame the low numbers on problems 
inherent within individual children and families. They presume that children from minority, especially poor, families are predisposed to using violence to solve problems, do not participate in reading activities, lack formal education, and have a particularly high rate of underachievement. Further, some (Herrnstein \& Murray, 1994; Jensen, 1969) claim these characteristics are inherited genetically and/or cannot be altered. Consequently, such children are not usually recognized as GT candidates. However, others (Oakes, 2005; Selden, 1999; Valencia, 2010; Valencia \& Suzuki, 2001) reject this "deficit thinking," choosing instead to focus on problems emanating from outside the child and family. Moreover, there is the tendency of school districts across the country to rely almost exclusively on outdated archetypes weighted heavily on culturally biased standardized intelligence tests and subjective teacher nominations (Valdés, 2003; Valencia, 2010; Valencia \& Suzuki, 2001).

But the predicament does not end there. Defining, identifying, and serving the gifted and talented have important, lifelong implications. Those who score highest on cognitive tests reap the benefits of society: they have access to the best colleges, most prestigious careers, and highest salaries (Valencia, 2010). Abundant research has shown that standardized tests such as the Stanford-Binet and the SAT are culturally biased against students of color (Margolin, 1994; Valdés, 2003; Valencia \& Suzuki, 2001). Moreover, students from poverty score lower than students from middle- and upper-class backgrounds, due to their lack of the opportunities that class privilege affords (Binet \& Simon, 1916; Margolin, 1994; Valdés, 2003; Valencia \& Suzuki, 2001). Oakes (2005) agrees, pointing to the tendency of gifted educators to mistake exposure to opportunity as inborn potential in their identification procedures, resulting in an inequitable system.

Added to the above is the ironic tendency of many educator preparation programs that require students to take coursework in learning and leadership theory while graduate certified teachers and administrators do not show a deep understanding of the research base and the ways of translating that knowledge into practice (Capper \& Frattura, 2008; Newcomb \& Mansfield, in press; Theoharis \& Brooks, 2012; Valencia, 2010). For example, contrary to popular belief, intelligence is not a biological or physical object that can be measured. Rather, learning potential can be viewed as a social construct that can be understood as existing on a continuum (Binet \& Simon, 1916; Fine, 2010; Jensen, 2006). Moreover, learning potential is not a fixed, inherited possession. Rather, intelligence and achievement interact with biological and social contexts in complex ways (Binet \& Simon, 1916; Fine, 2010; Jensen, 2006; Lindstrom, Hardert, \& Johnson, 1995; Lippman, 1922; Valencia, 2010). Despite the fact that many researchers in anthropology, psychology, and medicine have supported the idea that the brain is malleable and that cultural and contextual complexities influence brain development and school performance, a hegemonic discourse steeped in racist and classist ideologies has stubbornly held sway in the United States (Black, 2003; Fox, 2012; Lindstrom et al., 1995; Lippman, 1922; Margolin, 1994; Valencia, 2010).

The purposes of this article are to illumine the racist genealogy of gifted education policies and practices in the United States, demonstrate how deficit discourses continue today, and provide personal examples from the field on how educators can begin to question the status quo, resist taken-for-granted assumptions, 
and make substantive changes at the local level. I also aim to demonstrate how giftedness is an example of whiteness as property, or unearned white privilege, that, unintentionally or not, maintains a social caste system in schools.

\section{Methodology}

\section{Positioning the Author}

Before I earned a PhD and began working as a full-time tenure-track assistant professor of educational leadership and policy, I had been a teacher and gifted program administrator. In addition to being a certified teacher in Missouri, Nebraska, Colorado, and Texas, I am a certified principal with additional certifications in two areas: Gifted and Talented (G/T) and English as a Second Language (ESL). As early as 1985, I began to question the black-white divide in gifted education and advanced placement coursework and the gender divide in upper-level mathematics and sciences. My training, credentials, and personal and professional experiences as a teacher, administrator, and mother inform this work and my desire to understand the history of my field and the implication of the history in the present.

\section{Theoretical Framework}

The theoretical framework undergirding this study is based on Harris' (1993) work that defines the property functions of whiteness in the United States, which include:

1. The productive capacity of property: That is, our identities, like professional degrees, may be considered property due to the value they contribute to the owner's well-being and earning potential (p. 1733).

2. The right to use and enjoyment: In other words, whiteness is both identity and property. "It is something that can both be experienced and deployed as a resource." In other words, our identities can be a passive attribute or an active entity used as a resource, "deployable at the social, political, and institutional level to maintain control" (p. 1734).

3. Whiteness conceptualized as reputation and status property: That is, certain identities are valued over others in the United States: Namely, one's reputation and status is bound up in one's identity (pp. 1734-1735).

4. The absolute right to exclude: Just as the concept of property includes the absolute right to exclude, aspects of our identities have that same potential by naming some as "White" and others as "Black," with those in power determining "who was or was not white enough to enjoy the privileges accompanying whiteness" (p. 1737). 


\section{Policy Genealogy}

The purposes of this research required approaching the project from an historical methodology that enables researchers to become aware of our regimes of truth and put to the test our assumptive innocence (Coloma, 2011) and reveal "the motion and forces at work in our social reality" (Blount, 2008, p. 21). Indeed, conducting historical analyses draws attention to how the past, present, and future are interconnected and how understanding any context is to know the fundamental ways the past and future are implicated in the present (Hirsch \& Stewart, 2005). Furthermore, a critical examination of historical discourse enables an excavation of power relationships and cultural change in social settings, while concurrently locating ourselves as possible co-conspirators of knowledge creation and circulation and potential agents for the advancement of democratic projects committed to social justice (Coloma, 2011; Blount, 2008; Peräkylä, 2005). For example, textual analyses that examine power relations and historically constituted definitions and practices have potential to reveal how we have come to understand social phenomena, such as gifted education, the way that we do and conceivably can inspire us to ask important questions. This individual and collective reflection enables educators to "place our empirical, interpretive, and pedagogical practices in question in order to mark and evaluate what we have enabled and foreclosed as well as what the effects of our inclusions and exclusions have been" (Coloma, 2011, p. 185). Coloma further articulated the importance of questioning:

A sign of a healthy and thriving field is its ability to remain open to new questions and critiques and to be interrogative of its past and present, its accomplishments and desires, its limits and resistance, in order to imagine and move toward a future knowing that it does not know what it will become. (p. 210)

Importantly, Ferguson (1993) reminds us that the policy genealogist does not assume one historical point of origin but looks for "numberless beginnings whose faint traces and hints of color are readily seen by a historical eye" (p. 20). Thus, my data sources included archival materials from the American Psychological Association, American Sociological Association, American Philosophical Society Library, Cold Spring Harbor Laboratory Research Archives, George Mason University, Rockefeller Archives Center, and Truman State University Archives. In addition, important historical sources include biographical and autobiographical materials written by or about Lewis Terman and Leta Stetter Hollingworth (considered the Father and Mother of gifted education in the United States, respectively). In addition, findings from historical data sources are juxtaposed with more recent discourse in the public sphere, such as educator websites and parent blogs, to show the extensive connection between political ideology and systems of knowledge, as well as the importance of binary opposition in categorizing people to retain the status quo. 


\section{Findings}

\section{Foundational Discourses}

This section aims to show the racist genealogy of gifted education policies and practices in the United States by examining the writings of Lewis Terman and Leta Holllingworth, important founders of the discipline. It is important to note up front that their legacies have some positive aspects. For example, Dr. Hollingworth's research clearly disputed the belief in the inheritability of gender behaviors. Moreover, her work proved that an advanced education did not harm women's reproductive capabilities. Nor did the presence of the uterus disrupt women's ability to learn (Psychology's Feminist Voices, n.d.). Terman's contributions to the field of social science research are substantial in that he is on record as having conducted the longest survey of subjects in history (Green, 2000; Leslie, 2000). ${ }^{2}$ Their contributions to educational research notwithstanding, their work was framed by their eugenicist beliefs that scaffolded a pseudo science that is still influential today.

Eugenicists believe that poverty, crime and immorality prove poor genetics and have lobbied for negative eugenics policies such as restrictive immigration, antimiscegenation statutes, and the forced sterilization of the unfit. They have also advocated the dismantling of welfare and medical care. Undeniably, such entitlements promote reduction in infant mortality rates and frustrate eugenicists' aims to eradicate so-called unfit populations. In addition to forwarding negative eugenics strategies, eugenicists have worked to accomplish so-called positive eugenics policies, including education privileges and tax preferences for the genetically fit. They consider intelligence to be the most valuable human quality and have worked to construct what they have referred to as an aristogenic caste system whereby natural leaders would be identified early and cultivated for their proper roles in society. The most rewarding careers would go to the brightest citizens while the average and marginally educable would be made industrious laborers who yielded to the authority of the elite. Central to their utopian vision has been a society preserving white upper class power (Black, 2003; Chapman, 1988; Fox, 2012; Leslie, 2000; Lindstrom et al., 1995; Lippman, 1922; McClymer, Knoles, \& Pulda, 2001; Oakes, 2005; Quigley, 1995; Selden, 1999; Valencia, 2010; Valencia \& Suzuki, 2001).

Following the ideology of the organizations to which he belonged, Terman (1916) believed that "Spanish-Indian, Mexican, and Negro" children were "uneducable beyond the merest rudiments of training," destined as the "world's hewers of wood and drawers of water," incapable of becoming "intelligent voters" (pp. 91-92). He added:

Their dullness seems to be racial, or at least inherent in the family stocks from which they come....Children of this group should be segregated in special classes and be given instruction that is concrete and practical. They cannot master abstractions, but they can often be made efficient workers....There is no possibility at present of convincing society that they should not reproduce, 
although from a eugenic point of view they constitute a grave problem because of their unusually prolific breeding. (pp. 91-92)

In addition, Hollingworth popularized eugenics to generations of prospective classroom teachers to the point of integrating eugenic content into teacher education courses (Selden, 1999). Like Terman, Hollingworth devoted most of her attention to the study of the gifted and talented. While Hollingworth differed from Terman in that she worked to dispel the belief in biological determinism associated with testing gaps between men and women, both purported that the low numbers of "ethnics" in gifted and talented programs was evidence that children of non-white, non-middle/upper-class descent are less intelligent by nature (McClymer et al., 2001). Hollingworth's (1926) argument is examplified in the following:

Several surveys have been made to test the mentality of negro children. These surveys unexceptionally show a low average of intellect among children having negro blood. Comparatively few of these children are found within the range which includes the best one per cent of white children. It is, however, possible by prolonged search to find an occasional negro or mulatto child testing about 130 IQ... more than a mere suggestion that negro children furnish fewer gifted individuals than white children do, in the United States. (pp. 69-70)

Moreover, Terman and Hollingworth also examined giftedness in relation to socioeconomic status. Hollingworth (1926) claimed that exceptional people are from "well-educated, well-to-do families" with professional fathers (p. 53) and "found in schools located in good residential sections" (p. 56):

More recent and much wider investigation carried out by Terman has served only to confirm these findings. In a sample of a thousand gifted children there have occurred a few whose fathers are semi-skilled or unskilled manual laborers; so that the contribution of families at these economic levels is not absolutely nil. However, it is extremely meager; and the professional classes, who include not over two per cent of the total population, furnish over fifty per cent of the children testing in the highest one percent. (pp. 53-54)

Hollingworth (1926) does question the presence of gifted children in the poorer, unprofessional classes, but not in a way that one might expect. Rather, that poor, gifted children exist at all is cited as evidence that environmental hypotheses concerning giftedness must be altogether false:

There is no longer any doubt that in cities and towns gifted children are usually found in good environmental circumstances. Their parents have been able to attain and to maintain comfortable or luxurious modes of living in the great majority of cases. However, a few of the very gifted are born into homes where the father is an unskilled or semi-skilled manual laborer, and are reared without "advantages." These cases teach us that the gifted are not absolutely confined to any one set of environmental conditions....They also inform us that the intellectual gifts revealed by test are not due to superior environments, but are merely selected by them. If superior environment were the cause of high scores in tests, no child living from birth in squalor could score high. (pp. 57-58) 
The works to which Hollingworth is referring are the multiple studies Terman performed using his adaptation of Alfred Binet's IQ test, still referred to as the Stanford-Binet. According to Chapman (1988), the testing and tracking craze was fueled not only by eugenicists' beliefs and active legislative advocacy, but by the surge in US immigration and subsequent overcrowding in schools around 1920.

Some fellow psychologists at the time questioned the validity and reliability of the IQ tests as well as Terman's claim to the degree of hereditary influence on intelligence. Some academics also challenged the norms of the Stanford-Binet as biased against people who were not from white, upper-class backgrounds. Terman was also criticized for his rhetoric on the infallibility of IQ tests and the impact of test scores in determining the fate of an individual student's entire life course (Chapman, 1988). Some of Terman's associates-most notably Carl Brigham and Henry Goddard-recanted their earlier nativist beliefs and disassociated themselves from eugenic organizations (Black, 2003; Leslie, 2000). However, according to Church (1971), Terman and some of his associates purposefully snubbed important research findings to advance their political agenda. Moreover, Terman's beliefs on the coupling of giftedness with whiteness and wealth were touted by some in the daily news and monthly magazines, and the average citizen was deceived (Black, 2003; Chapman, 1988; Selden, 1999). Thus, IQ testing and tracking as sorting mechanisms became standard practices in American schools.

This tracking procedure became a type of property in that those from certain family stocks were destined to be segregated in "special" classes, which would ensure that the owners of the "low" label would receive less resources in terms of quality curriculum as well as earning potential as adults. Meanwhile, those owning the gifted label received special treatment that would "groom" them for important positions in society, resulting in an accumulation of material wealth that was just not possible for those not owning the gifted label.

\section{Contemporary Discourses}

In addition to excavating the historical discourse around gifted education in the United States, relatively recent discourse was studied. The present section limits its focus to the discourse of professional organizations that aim to serve gifted students and their families, as well as to popular discourse that aims to reach a similar audience. While communicated more subtly, this more recent discourse shows troubling similarities to the ideas forwarded by the founders of the field.

For example, a popular magazine published an article, "Growing Up Gifted: Identifying and Educating Gifted \& Talented Kids (Jain, 2007), wherein a school principal and professor were interviewed about the under-representation of minority students in gifted programs in Austin, Texas. The school principal remarked that the disproportion amongst various schools made perfect sense since "clusters of gifted families" were positioned geographically around town, alluding to the existence of residential segregation and the tendency of gifted programs to be larger and more abundant in affluent neighborhoods. The professor that was interviewed for the story 
retorted, "I would not think that Austin would have more or less gifted and talented students than any other place.... I am so very weary of society priggishly equating talent with financial wealth" (p. 7). The author goes on to explain that despite varying opinions concerning the racial make-up of the gifted population, those earmarked for services need a "radically different" education than the non-gifted (Jain, 2007). Davidson (2004) agrees, adding, "Raising exceptional children can be expensive particularly when schools don't meet their needs" (p. 62). The website of the National Association for Gifted Children warns parents that understanding giftedness demands an "investment of time, money, and energy" (NAGC, n.d.-a). However, there is no discussion on what a parent should do if they are raising a gifted child while relying on limited financial and other resources. This omission seems to presume that the gifted can only come from families who have the time, money, and energy to meet the demands of raising an exceptional child.

I then turned to the Texas Association for the Gifted and Talented (TAGT) since that is the organization I was directly associated with while being a GT teacher and program administrator. At the state level, similar assumptions seem to prevail. For example, indicators of giftedness include a great appetite for books, puzzles, and challenging toys, along with the tendency of the child to fantasize often (TAGT, n.d.). Similar to the national discourse, this state's discourse refers parents and teachers to costly items for purchase - implied in the ads are the notion that if your child loves these items, then surely this is proof they are gifted. Meanwhile, no low-cost or cost-free alternatives are offered. Nor is there any discussion on whether non-gifted kids would enjoy these expensive books and toys. Moreover, there is no mention of how to tell if one's child is actually fantasizing beyond behavioral norms - one of the indicators of giftedness.

Interestingly, a popular parent website, Great Schools, reports on testing data, demographics, and other measurements of how well neighborhood schools are doing (which we know from the above discussion, strongly correlates with wealth). In addition, they publish helpful articles for parents - including articles discussing giftedness and its connection to wealth and whiteness:

The entire gifted industry has come under fire as a bastion of elitism and privileged helicopter mothers gone wild. The makeup of gifted programs only fuels such charges. While 8 percent of white students and 13 percent of Asian students were in public school gifted programs in 2006, only 3.6 percent of blacks and 4.2 percent of Hispanics were.... In affluent Montgomery County, MD, about 60 percent of white and Asian students qualified for gifted programs.... Some areas are like Lake Woebegone, where all children are above average. (Robinson, n.d.)

The above quote points to a variety of ways this "industry" of gifted education has been criticized. First is the concept of "helicopter mothers"; while limited research shows that the phenomenon occurs to varying degrees across genders and classes, the typical scenario is the wealthy stay-at-home mom (Somers \& Settle, 2010). Secondly, most professionals who support gifted programs claim they should be limited to no more than the top 10 percent because, by their very definition, the gifted are exceptional and deserve an exceptional education (NAGC, n.d.-b). However, in one of the wealthiest 
counties of the United States, about two-thirds of students of European and Asian descent qualify for gifted programs. Robinson's (n.d.) use of the fictional "Lake Woebegone" not only conjures visions of a fantasy world, but also connects this bucolic portrait directly with whiteness and wealth. Add to this, the tendency of some to spend large sums of money on tutoring programs to prepare their children to do well when testing for admission to gifted programs (Robinson, n.d.). Interestingly, NAGC cautions their web site readers about the "trickiness" of semantics and warns parents to "challenge those who cry 'elitism' and explain the true meaning of the term," because "in fact, gifted children are elite," as is anyone else in society who does "important" things (NAGC, n.d.-a).

In addition to the privilege-giftedness connection, there are difficulties defining giftedness. For example, Gagné believes giftedness is limited to the top $10 \%$ of students and is only expressed spontaneously, without training (NAGC, n.d.-b) while the federal government defines giftedness broadly to include a variety of aptitudes:

The term gifted and talented student means children and youths who give evidence of higher performance capability in such areas as intellectual, creative, artistic, or leadership capacity, or in specific academic fields, and who require services or activities not ordinarily provided by the schools in order to develop such capabilities fully. (NAGC, n.d.-b)

Importantly, NAGC acknowledges there is no agreed upon definition of giftedness (n.d.b). In addition to difficulties defining giftedness,

Controversy also stems from the process by which school districts determine giftedness. Many rely entirely or in part on an IQ test, but experts caution that many tests for giftedness have serious limitations. At best, they provide a snapshot - a rather fuzzy snapshot at that - of the child on the day of the test. Most tests do not measure artistic or social abilities and may give short shrift to a child with extraordinary math abilities, but ordinary talents in other areas. (Robinson, n.d.)

And when districts do use alternative assessments such as classroom observations and grades, their inherent subjectivity is prone to garner criticism. For example, a student who exhibits behavior problems or who is not fluent in English may not be considered gifted irrespective of his or her intelligence, creativity, or other characteristics (Robinson, n.d.). However, "until some scientific breakthrough is developed, we will rely on the IQ score to approximate how mentally gifted a person may be" (NAGC, n.d.-a). The National Association for Gifted Children explains intellectual capacity this way:

If intelligence were something you could see, touch, and weigh, it would be something like a can of paint. The genius would have a gallon, the person who has severe retardation, only half a pint. The rest of us would have varying amounts between these extremes, with the majority possessing about two quarts. (NAGC, n.d.-a)

The above quote, while part of the current professional discourse, shows a lack of understanding about intelligence. Rather than recognize learning potential as something that is fluid and determined by complex interface between biology and context, it is 
viewed as a "container" of sorts. False analogies like this not only confuse parents, professionals, and the public at large as to the true nature of learning potential, but also add to the misconception that intelligence is a physical object that can be possessed. And possessions can be purchased or inherited.

\section{Discussion}

Reflecting on the genealogy of gifted education in the United States reawakens the collective memory, reminding us of the racist underpinnings of the field. Terman, the "father" of gifted education, and Hollingworth, the "mother" of gifted education, were public proponents of eugenics and used their privileged positions in academe to forward their pseudo science. The political ramifications of the coupling of eugenics and gifted education resulted in the denial of resources to people deemed "less than" and clearly favored those falsely labeled as superior. Despite the fact that many geneticists, anthropologists, and even educational psychologists of their time posited that an interplay between both heredity and environment influenced intellectual development and school achievement, neither Hollingworth nor Terman appeared to consider alternative explanations for their theories. For example, Binet and Simon (1916), who developed the original IQ test, warned researchers and practitioners alike that their scale should only be used to determine opportunity and achievement gaps and subsequent curricular and pedagogical adaptations to help students catch up. Almost 100 years ago, Binet and Simon's research showed that score patterns correlated with wealth and opportunity. In France, their population and sample was almost entirely white. However, the Binet and Simon Scale clearly showed, even back then, that access to opportunity was what needed to be remedied. Terman and Hollingworth failed to consider their findings in the US context where their population and samples were more diverse than Binet and Simon's (1916) and where wealth closely aligned with racial oppression.

Examining more current discourse shows disturbing similarities. For example, Hernstein and Murray (1994) posit a causal effect between IQ and ability to generate wealth (or the propensity to criminal activity). Further, like the eugenicists of centuries past, Hernstein and Murray (1994) claim the inheritability of IQ, rejecting current and former research that show strong relationships between context and performance on tests (Chapman, 1988; Lindstrom et al., 1995; Lippman, 1922; Margolin, 1994).

Still troubling as well is the perpetuated notion that intelligence in "normal" people is a fixed construct. In other words, it is impossible to transform the ordinary into the gifted by providing idyllic home and enriching school environments. Yet, claims are made concerning the fluidity of intelligence when it comes to the truly gifted, and demands are made concerning bolstering resources for the gifted lest they lose their learning potential (Davidson, 2004; Jain, 2007).

Add to this the fact that the National Association for Gifted Children (NAGC) is unable to present a universally agreed upon definition of gifted or the best means for identifying children deserving of this label. Nor do they agree on the specific definition of 
intelligence or how to properly serve the gifted once they are identified. Further, the federal definition of giftedness, "children and youths who give evidence of higher performance capability... who require services or activities not ordinarily provided by the schools in order to develop such capabilities fully" (NAGC, n.d.-b), begs important questions: Why are these services or activities not ordinarily provided by schools? Do not all children have potential and capability? How do we know if we are not providing opportunities at schools for them to demonstrate their potential beyond state and local mandated benchmarks and high-stakes testing?

Finally, one must ask, "How is it that $60 \%$ of Whites and Asians in wealthy Montgomery County, MD are identified as gifted?" Can it be that these wealthier schools are providing services not ordinarily provided by most schools, thus giving even average students ample opportunities to develop and show their capabilities? In other words, money begets resources, and resources beget opportunities, and opportunity generates the possibility that students' capabilities will be developed to the fullest. The past and present discourse would lead us to believe that all people fall into one of two categories: gifted or not gifted. Moreover, these discourses show a distinct separation between the wealthy and the poor, along with the continued segregation of White and Black in terms of owning giftedness. Giftedness is forwarded as an inherited property with valuable resources and opportunities attached.

Similar to Harris (1993) positing that racial identity and property are tightly entwined and that whiteness provides status and privileges, both public and private discourse, past and present, positions giftedness as a status label, a form of property with whiteness and wealth as the only currency capable of attaining it. Thus, the gifted identification process is another type of classification procedure that simultaneously acts as an "aspect of identity and a property interest...something that can both be experienced and deployed as a resource" (p. 1734). Similar to the social and material distinctions bound up in racial identity labels noted by Harris (1993), segregating students according to the gifted/non-gifted label reinforces a social hierarchy in schools, despite the fact that de jure segregation is no more.

\section{Implications and IIlustrations}

The continued labeling of students by IQ score and the resultant allocation (or withholding) of resources, opportunity, and the distribution of knowledge are indications of continued race and class biases. These findings have serious implications for school leaders as they work to fulfill the public trust, that is, "to promote social justice and ensure that individual student needs inform all aspects of schooling" (ISLLC, 2008, p. 15).

I was lucky that my first principal was open to discussing issues of social justice and committed to meeting the needs of all students - far earlier than the 2008 ISLLC Standards. He was an insightful and sensitive person who encouraged me to research the questions I had concerning the racial, class, and gender divides in various aspects of educational access and achievement. We then followed up with conversations about 
my findings, discussing what was possible to change within our purview of power. We discussed how changing hearts and minds takes time, but if we had evidence of what a democratic classroom looked like, as well as data to show it leads to a higher level of mastery learning for all children, we might have an easier time garnering support to implement needed changes at the school level. Thus, my classroom became a type of lab school to test our ideas in real time.

Instead of relying on random selection or allowing the teacher with the most seniority to skim all the good kids for her class, my principal very carefully selected students to make my primary grade classroom more heterogeneous than the typical population. That is, instead of resembling the typical bell curve, the make-up of my classroom was flat, with clusters of representation across the spectrum, including those identified as gifted, intellectually impaired, and/or behavioral impaired.

I used research-based texts ${ }^{3}$ to design and implement an integrated, enriched curriculum. Following my undergraduate training, I implemented "unit teaching," whereby all the knowledge and skills required of the district in scope and sequence were integrated within topical studies that young children find interesting. For example, required concepts (and allocation of time) for science, social studies, writing, spelling, art, and so on, were integrated into various units of study chosen by the students. Favorites included "Dinosaurs" and "The Solar System." Instead of breaking the day into 30-minute intervals to "cover" spelling, writing, science, social studies, etc., students worked in heterogeneous "cooperative learning" groups in two-hour blocks of time in the afternoons while I circulated and facilitated critical thinking and discussion.

In the core areas of math and reading, to show growth and ensure that all students worked toward mastery learning at their own pace, each student was given pre- and post-tests in each topical/unit area. Based on pre-test scores, small groups of students received guided instruction. Frequent checks for understanding informed whether re-teaching was necessary. Students took the post-test as they were ready and moved on to the next unit as they mastered material. Interestingly, about $20 \%$ of students, regardless of reading ability, "tested out" of the current grade level math curriculum. Thus, this group of students completed the math one to two years above their current grade level. Similarly, but less dramatically, reading growth was documented. These small groups that met for guided instruction, while fluid, were more predictable and less dynamic than the math groups. Guided instruction in math and reading took place during the morning hours while the rest of the students worked independently and in small groups at learning centers placed throughout the room. Learning centers consisted of tiered instructional activities that varied between remedial, reinforcement, and challenge levels. Students shared their products and their discoveries during large group discussion blocks before and after lunch.

Students across the spectrum of "labels" showed growth across all curricular areas. In fact, students labeled "LD" (learning disabled) in one core area, such as reading, sometimes surpassed peers in math. Similarly, those labeled "gifted" may have worked two years above grade level in reading, but completed the grade level mathematics at an average pace. The bottom line? All students (except those considered at the time to be moderately handicapped) met all the criteria for their grade level and outperformed their peers in the non-integrated classrooms on all post-tests. 
Even the children labeled as "MR" (mentally retarded) showed significant growth in all areas (e.g., pre-test scores of 0 and post-test scores of 30-60\%), much to their parents' delight. The parents of those labeled as "gifted" were gratified, too, as their children were challenged and allowed to work a year or two above grade level, when appropriate. Also, the parents of high achievers appreciated the extra help their children received in areas that were not their particular strengths. Finally, parents of the "average" child were satisfied, because their children were "allowed" to partake of an enriched curriculum that both supported and challenged them beyond what was typical in their prior experiences.

I wish I could relay that the successes of the pilot lab classroom led to significant attitudinal and structural changes at the school level. However, after two years, my transformative-minded principal was replaced by someone who was closed-minded to this paradigm shift. My early and eager attempts at conversation with him were met with accusations of my naiveté, and the declaration that the color, class, and gender divides in educational access and achievement were "just the way things are" (Mansfield, 2007).

\section{Conclusion}

In light of the troubling history of IQ testing and gifted education research and the consideration that no one can agree on the definition of intelligence or giftedness or exactly how to measure it, along with the evidence that current policy and practices are hurting many minorities and serving white privilege, it seems reasonable to conclude that the current situation is faulty and needs to be transformed. Thus, rather than accepting the color and class divides in gifted education as "just the way things are," (Mansfield, 2007), educational leaders can act as defectors of presumption while actively practicing an ecology of love (Keller, 2004).

Accordingly, this manuscript does not end with critique only. Rather, the personal examples shared show promise for not only rejecting explicit and implicit racism, but also embracing more inclusive, democratic schooling practices that foster both excellence and equity for all students ${ }^{4}$ while stemming the tide of "educational genocide" (Knaus \& Rogers-Ard, 2012).

It is time to disrupt the thinking that equates giftedness with whiteness and wealth, perpetuating the "whiteness as property" dilemma. ${ }^{5}$

\section{Notes}

1. I refrain from using the word, "minority" since many of my teaching experiences have been in majority-minority schools. Also, definitions of "minority" students have changed over time. For example, according to local archives, in the early to midtwentieth century, "Italian" was considered a separate race in the community in which I taught. Thus, I use the word, "minoritized" to indicate the fluidity of the 
concept as well as to indicate that individual and group minority status labels are designated by those in power. In gifted education, minoritized students have included students who are non-white from lower socio-economic backgrounds. Until recently, this included students from various Asian countries such as China, South Korea, and Vietnam. However, over the past two decades, the phenomenon of the "model minority" has changed the make-up of gifted programs to include large numbers of students of Asian background in many communities. It is beyond the scope of this paper to discuss the "model minority" concept in detail. See Nicolas Hartlep's (2013) work for a more robust explanation.

2. According to Leslie (2000), Terman studied 1,000 gifted children over his long career. The study continued after his death and after 80 years, at least 200 of the participants were still alive and continued to be tracked.

3. Excellent resources for educators interested in translating theory to practice include: Copple, Bredekamp, Koralek, and Charner, n.d.; Gindis, Ageyev, Miller, Miller, and Kozulin, 2003; Jacobs and Crowley, n.d.; Jensen, 2006; Johnsen, 2004; Neas, n.d., Piaget, 1947/2001; Piaget, 1971/1998; Piaget, 1974; Piaget, Inhelder, and Weaver, 1950/1972; Valdés, 2003; Vygotsky, John-Steiner, Cole, Scribner, and Souberman, 1980; Winebrenner, 1992.

4. See the following resources for additional strategies: Brooks \& Arnold, 2013; Capper \& Frattura, 2008; Jean-Marie \& Mansfield, 2013; Jensen, 2006; Mansfield, 2014; Oakes, 2005; Skrla, McKenzie, \& Scheurich, 2009; Theoharis, 2009; Theoharis \& Brooks, 2012; Winebrenner, 1992.

5. Harris (1993) also calls for the de-legitimatization of the property interest in whiteness via affirmative action measures that are beyond the scope of this paper to discuss.

\section{References}

Binet, A. \& Simon, T. (1916). The development of intelligence in children: The BinetSimon Scale. (Translated by E. S. Kite). Baltimore, MD: Williams \& Wilkins Co.

Black, E. (2003). War against the weak: Eugenics and America's campaign to create a master race. New York, NY: Four Walls Eight Windows.

Blount, J. (2008). "History as a way of understanding and motivating: Social justice work in education." In F. Bogotch, J. Beachum, J. Blount, J. Brooks, \& F. English (Eds.), Radicalizing educational leadership: Dimensions of social justice (pp. 1737). Rotterdam, Neitherland: Sense Publishers.

Brooks, J. S., \& Arnold, N. W. (Eds.) (2013). Antiracist school leadership: Toward equity in education for America's students. Charlotte, NC: Information Age Publishing.

Capper, C. A., \& Frattura, E. M. (2008). Meeting the needs of students of all abilities: How leaders go beyond inclusion. Thousand Oaks, CA: Corwin. 
Chapman, P. (1988). Schools as sorters: Lewis M. Terman, applied psychology, and the intelligence testing movement, 1890-1930. New York, NY: New York University Press.

Church, R. L. (1971). Educational psychology and social reform in the Progressive Era. History of Education Quarterly. 11(4), 390-405.

Coloma, R. S. (2011). Who's afraid of Foucault? History, theory, and becoming subjects. History of Education Quarterly, 51(2), 184-210.

Copple, C., Bredekamp, S., Koralek, D., \& Charner. K. (n.d.). Developmentally appropriate practice: Focus on children in first, second, and third grades. Washington, DC: National Association for the Education of Young Children.

Davidson, J. (2004). Genius denied: How to stop wasting our brightest young minds. New York, NY: Simon and Schuster.

Ferguson, K. E. (1993). The man question: Visions of subjectivity in feminist theory. Berkeley, CA: University of California Press.

Fine, C. (2010). Delusions of gender: How our minds, society, and neurosexism create difference. New York, NY: WW Norton and Co.

Fox, M. (2012, Nov. 1). "Arthur R. Jensen dies at 89; Set off debate about I.Q." New York Times. Retrieved from http://www.nytimes.com/2012/11/02/science/arthur-rjensen-who-set-off-debate-on-iq-dies.html?pagewanted=all\&_r=0

Gindis, B., Ageyev, V.S., Miller, S. M., Miller, S., \& Kozulin, A. (2003). Vygotsky's educational theory in cultural context. New York, NY: Cambridge University Press.

Green, C. (2000). Classics in the history of psychology: Autobiography of Lewis M. Terman. Retrieved from http://psychclassics.yorku.ca/Terman/murchison.htm

Harris, C. I. (1993). Whiteness as property. Harvard Law Review, 106(8), 1707-1791.

Hartlep, N. D. (2013). The model minority stereotype: Demystifying Asian American success. Charlotte, NC: Information Age Publishing.

Herrnstein, R. J., \& Murray, C. (1994). The bell curve: Intelligence and class structure in American life. New York, NY: Free Press.

Hirsch, E. \& Stewart, C (2005). Introduction: Ethnographies of historicity. History and Anthropology, 16(3), 261-274.

Hollingworth, L. S. (1926). Gifted children: Their nature and nurture. New York, NY: Macmillan.

(ISLLC). (2008). Educational leadership policy standards: ISLLC 2008. Council of Chief State School Officers, Washington, DC. Retrieved from http://www.ccsso.org/Documents/2008/Educational_Leadership_Policy_Standard s_2008.pdf

Jacobs, G., \& Crowley, K. (n.d.). Supporting students, meeting standards: Best practices for engaged learning in first, second, and third grades. Washington, DC: National Association for the Education of Young Children. 
Jain, S. (2007). "Growing up gifted: Identifying and educating gifted \& talented kids," In: Parent: Wise Austin (6-9). Austin, TX: Pleticha Publishing. Retrieved from http://www.austingifted.org/docs/ParentWise_2007.pdf

Jean-Marie, G., \& Mansfield, K. C. (2013). "Race and racial discrimination in schools: School leaders' courageous conversations." In J. S. Brooks \& N. W. Arnold, (Eds.) Anti-racist school leadership: Toward equity in education for America's students, (pp. 19-36). Charlotte, NC: Information Age Publishing.

Jensen, A. R (1969). How much can we boost IQ and scholastic achievement? Harvard Educational Review, 39, 1-123.

Jensen, E. (2006). Enriching the brain: How to maximize every learner's potential. San Francisco, CA: Jossey-Bass.

Johnsen, S. K. (2004). Identifying gifted students: A practical guide. Waco, TX: Prufrock Press and Texas Association for the Gifted and Talented.

Keller, C. (2004). "The love of postcolonialism: Theology in the interstices of empire." In C. Keller, M. Nausner, \& M. Rivera (Eds), Postcolonial theologies: Divinity and empire (pp. 221-242). St. Louis, MO: Chalice Press.

Knaus, C. B., \& Rogers-Ard, R. (2012) Educational genocide: Examining the impact of national education policy on African American communities. ECI Interdisciplinary Journal for Legal and Social Policy, 2(1), Article 1. Retrieved from http://ecipublications.org/ijlsp/vol2/iss1/1

Leslie, M. (2000). The vexing legacy of Lewis Terman. Retrieved from http://alumni.stanford.edu/get/page/magazine/article/?article_id=40678

Lindstrom, F. B., Hardert, R. A., \& Johnson, L. L. (Eds.). (1995). Kimball Young on sociology in transition, 1912-1968: An oral account by the 35th president of the ASA. Lanham, MD: University Press of America.

Lippman, W. (1922). "Debunking intelligence experts: Walter Lippmann speaks out." Six articles archived from the New Republic, 32, 412-417. Retrieved from http://historymatters.gmu.edu/d/5172/

Mansfield, K. C. (2007). "Just the way things were" or malicious intent?: One professor's attempt to facilitate truth. Journal of Research on Leadership Education, 2(2), 17.

Mansfield, K. C. (2014). How listening to student voices can inform and strengthen social justice research and practice. Educational Administration Quarterly, 50(3), $392-430$.

Margolin, L. (1994). Goodness personified: The emergence of gifted children. New York, NY: Aldine de Gruyter.

McClymer, J., Knoles, L., \& Pulda, A. (2001). Eugenics in the culture wars of the 1920s: Some approaches to studying a neglected topic. Retrieved from http://www.assumption.edu/ahc/1920s/

Mclntosh, P. (1990). White privilege: Unpacking the knapsack. Retrieved from http://ted.coe.wayne.edu/ele3600/mcintosh.html 
National Association for Gifted Children (NAGC). (n.d.-a). Giftedness and the gifted: What's it all about? Retrieved from http://www.nagc.org/index.aspx?id=121

National Association for Gifted Children (NAGC). (n.d.,-b). What is giftedness? Retrieved from: http://www.nagc.org/index.aspx?id=574

Neas, L. M. R. (n.d.). Classroom themes to capture students' attention. Retrieved from http://www.brighthubeducation.com/classroom-management/64535-creativeclassroom-themes-for-k-8/

Newcomb, W. S., \& Mansfield, K. C. (in press). Purposeful presence: Situating social justice in leadership education. Scholar-Practitioner Quarterly, 7 (3).

Oakes, J. (2005). Keeping track: How schools structure inequality. New Haven, CT: Yale University Press.

Peräkylä, A. (2005). Analyzing talk and text. In: N. K. Denzin \& Y.S. Lincoln (Eds.), The Sage handbook of qualitative research, ( $3^{\text {rd }}$ ed.) pp. 869-886. Thousand Oaks, CA: SAGE Publications.

Piaget, J. (1947/2001). The psychology of intelligence. London, UK: Routledge.

Piaget, J. (1971/1998). Mental imagery in the child: Jean Piaget: Selected works. London, UK: Routledge.

Piaget, J. (1974). The origins of intelligence in children. Madison, CT: International Universities Press

Piaget, J., Inhelder, B., \& Weaver, H. (1950/1972). The psychology of the child. New York, NY: Basic Books.

Psychology's Feminist Voices. (n.d.). Leta Hollingworth. Retrieved from http://www.feministvoices.com/leta-hollingworth/

Quigley, M. (1995). The roots of the I. Q. debate: Eugenics and social control. Retrieved from http://www.hartford-hwp.com/archives/45/034.html

Robinson, G. (n.d.). Gifted - or just privileged? Retrieved from http://www.greatschools.org/parenting/learning-development/7089-giftededucation-and-program-controversy.gs

Selden, S. (1999). Inheriting shame: The story of eugenics and racism in America. New York, NY: Teachers College Press.

Singleton, G. E., \& Linton, C. W. (2005). Courageous conversations about race: A field guide for achieving equity in schools. Thousand Oaks, CA: Corwin Press.

Skrla, L. E., McKenzie, K. B., \& Scheurich, J. J. (Eds.) (2009). Using equity audits to create equitable and excellent schools. Thousand Oaks, CA: Corwin.

Slocumb, P., \& Payne, R. (2000). Removing the mask: Giftedness in poverty. Highlands, TX: Aha! Process.

Somers, P., \& Settle, J. (2010). The helicopter parent: Research toward a typology. College and University, 86(1), 18-27. 
TAGT. (Texas Association for the Gifted and Talented). (n.d.) What is giftedness? Retrieved from http://txgifted.org/what-giftedness/

Terman, L. M. (1916). The measurement of intelligence: An explanation of and a complete guide for the use of the Stanford revision and extension of the BinetSimon scales. Boston, MA: Houghton Mifflin.

Theoharis, G. (2009). The school leaders children deserve: Seven keys to equity, social justice, and school reform. New York, NY: Teachers College Press.

Theoharis, G., \& Brooks, J. S. (Eds) (2012). What every principal needs to know to create equitable and excellent schools. New York, NY: Teachers College Press.

Valdés, G. (2003). Expanding definitions of giftedness: The case of young interpreters from immigrant communities. Mahwah, $\mathrm{NJ}$ : Lawrence Erlbaum.

Valencia, R. R. (2010). Dismantling contemporary deficit thinking: Educational thought and practice. New York, NY: Routledge.

Valencia, R. R., \& Suzuki, L. A. (2001). Intelligence testing and minority students: Foundations, performance factors, and assessment issues. Thousand Oaks, CA: SAGE.

Vygotsky, L. S., John-Steiner, V., Cole, M., Scribner, S., \& Souberman, E. (1980). Mind in society: Development of higher psychological processes. Cambridge, MA: Harvard University Press.

Winebrenner, S. (1992). Teaching gifted kids in the regular classroom. Minneapolis, MN: Free Spirit Publishing. 